\title{
Comparative Study of Molecular Size and Structure of Exo- $\beta$ - Glucanases from Kluyveromyces and Other Yeast Genera: Evolutionary and Taxonomic Implications
}

\author{
MARC-ANDRÉ LACHANCE† AND HERMAN J. PHAFF \\ Department of Food Science and Technology, University of California, Davis, California 95616
}

\begin{abstract}
A comparative study was made of the molecular weights of the exo- $\beta$-glucanases (EC 3.2.1.58) of species belonging to Kluyveromyces or to various other yeast genera. Their immunological distances were determined with the exo- $\beta$-glucanases from Kluyveromyces fragilis, $K$. phaseolosporus, $K$. aestuarii, and Saccharomyces cerevisiae as references. The molecular sizes of the enzymes were estimated by polyacrylamide gel exclusion chromatography, and the immunological comparison was done by the microcomplement fixation technique. The molecular weights of the enzymes from ascomycetous species ranged from $24 \times$ $10^{3}$ to $63 \times 10^{3}$, but the majority of the species, including most species of Kluyveromyces, contained exo- $\beta$-glucanases with molecular weights between 35 $\times 10^{3}$ and $45 \times 10^{3}$. Immunological identity was observed among the exo- $\beta$ glucanases from the following species: $K$. fragilis (reference species), $K$. marxianus, $K$. bulgaricus, $K$. cicerisporus, and $K$. wikenii; closely related were $K$. phaseolosporus (reference species), $K$. delphensis, $K$. lactis, $K$. vanudenii, and $K$. drosophilarum; also closely related were Saccharomyces cerevisiae (reference species), $S$. italicus, $S$. uvarum, and $S$. chevalieri. The exo- $\beta$-glucanase from $K$. aestuarii showed low degrees of homology with those from all tested species of Kluyveromyces. It was concluded from these data that ascospore shape has little significance in the phylogeny of this genus. Other evolutionary implications are discussed.
\end{abstract}

The genus Kluyveromyces was established by van der Walt (17) when he isolated from soil an ascosporogenous yeast, $K$. polysporus, capable of producing up to 60 spores per ascus. Shortly afterward, he described a second species $(K$. africanus) and later emended the generic diagnosis (18), which permitted the transfer to Kluyveromyces of several Saccharomyces species that formed up to four kidney-shaped or spheroidal spores per ascus. The genus Kluyveromyces is presently based on: the ability of its species to release reniform or spheroidal ascospores, soon after their formation, by dehiscence from the ascus; the smooth surface of the ascospores; and vigorous fermentation of glucose (19).

In discussing the phylogeny of Kluyveromyces, van der Walt proposed (19) that the genus evolved along two main lines of development. His views were patterned after Wickerham's (24) concept of evolution in the genus Hansenula. The two postulated lineages were distinguished on the basis of ascospore morphology (reniform versus spheroidal), each

† Present address: Department of Plant Sciences, University of Western Ontario, London, Ontario N6A 5B7, Canada. group containing species that were thought to have evolved toward more advanced states, characterized by the acquisition of the abilities to synthesize $\alpha$-glucosidase or $\beta$-galactosidase or to produce ascospores in numbers greater than four per ascus.

Important contributions were made recently to the study of phylogeny in Kluyveromyces; these were based on the nuclear deoxyribonucleic acid (DNA) base composition of its species (10), their DNA/DNA base sequence comparison $(2,8,9)$, and a factor analysis of their functional phenotypes (14). The results obtained by these different approaches agree in part with each other and with van der Walt's postulated lineages, but several contradictions are also evident.

This paper reports a comparative study of the exo- $\beta$-glucanases (EC 3.2.1.58) extracted from the various species of Kluyveromyces and from representatives of other yeast genera. Various properties have been reported of exo- $\beta$-glucanases extracted and purified from $K$. fragilis, Hansenula anomala, Saccharomyces cerevisiae (1), K. aestuarii (6), and $K$. phaseolosporus (21). Some properties of the enzymes (e.g., substrate specificity and response to $\mathrm{pH}$ ) appear 
rather similar, whereas others (e.g., kinetic constants) vary significantly.

The results presented here are based on: (i) a comparison of the molecular weights of these enzymes, and (ii) a study of their immunological relatedness by the microcomplement fixation technique (3). For the latter, $K$. aestuarii, $K$. fragilis, K. phaseolosporus, and Saccharomyces cerevisiae were used as reference species. It is shown how the results obtained relate to the evolution and classification of the species of Kluyveromyces.

\section{MATERIALS AND METHODS}

Yeast strains. The yeasts used in this study were obtained from the yeast culture collection of the Department of Food Science and Technology, University of California, Davis. The strain numbers are listed in Tables 1 and 2.

Enzyme preparations. The purification of exo- $\beta$ glucanases to antigenic homogeneity was done by a combination of ion-exchange and gel exclusion chromatographic procedures, as described previously $(1,6$, 21). Protein homogeneity was based on reaching a constant specific activity during chromatography on molecular exclusion and ion-exchange gels (eluted isoionically) and on the formation of a single precipitin band when the preparations were allowed to react with antisera prepared against them. In the case of $K$. aestuarii, additional evidence for homogeneity was obtained by immunoelectrophoresis (6).

Preparations for which homogeneity was not required (those used as heterologous antigens) were obtained from cultures grown in two 1,500 -ml batches of yeast autolysate $(0.5 \%)$-glucose $(5 \%)$ in shaken, 2,800-ml Fernbach flasks. The cultures were grown at room temperature until the stationary phase was reached. The cells were harvested by centrifugation and suspended in sodium succinate buffer $(0.05 \mathrm{M}, \mathrm{pH}$ 5.5) as a thick suspension. They were then disrupted in a Braun homogenizer (Bronwill Scientific, Rochester, N.Y) and centrifuged to remove cell walls and debris. The supernatants were dialyzed to equilibrium against sodium succinate buffer $(0.005 \mathrm{M}, \mathrm{pH} 6.2)$, centrifuged at $45,000 \times g$ for $30 \mathrm{~min}$, and applied to columns of diethylaminoethyl-agarose (diethylaminoethyl-Bio-Gel A, Bio-Rad Laboratories, Richmond, Calif.) previously equilibrated with sodium succinate buffer $(0.01 \mathrm{M}, \mathrm{pH}$ 6.2). After the columns were washed with equilibration buffer until no further protein was eluted, the enzymes were eluted with sodium succinate buffer $(0.05 \mathrm{M}, \mathrm{pH} 5.0)$ containing $0.45 \mathrm{M}$ sodium chloride. The activity peaks were located in the elution fractions by a rapid method described elsewhere (5). The concentrated exo- $\beta$-glucanase solutions ( 3 to $5 \mathrm{ml}$ ) obtained in this manner contained from 0.1 to $10 \mathrm{U}$ of glucanase activity. One unit is defined as the amount of enzyme that will release 1 $\mu \mathrm{mol}$ of glucose per min, at $30^{\circ} \mathrm{C}$ and $\mathrm{pH} 5.2$, from 0.5\% laminaran (Nutritional Biochemicals Corp., Cleveland, Ohio).

Determination of molecular weights. The molecular weights of exo- $\beta$-glucanases were estimated by gel exclusion chromatography on Bio-Gel P-100 or P150 , according to the method of Whitaker (23). The columns were calibrated with proteins of known molecular weights: ribonuclease $A, 13,680$; chymotrypsinogen A, 25,650; and chicken ovalbumin, 46,000 (all from Worthington Biochemicals Corp., Freehold, N.J.); pepsin, 35,500 (Sigma Chemical Co., St. Louis, Mo.); and bovine serum albumin, 66,210 (Miles Research Products, Inc., Elkhart, Ind.). Their elution peaks were determined by measuring the absorbance $(280 \mathrm{~nm})$ of the elution fractions. The activity peaks of exo- $\beta$-glucanases were located by assaying the column fractions for their hydrolytic activity on laminaran and $p$-nitrophenyl- $\beta$-D-glucoside (Calbiochem, San Diego, Calif.).

A computer algorithm was used to determine the centers of the elution peaks accurately by a combination of two-curve fitting methods. Each elution quotient was calculated as the ratio of elution volume over void volume. The latter was determined for each run as the elution volume of blue dextran 2000 (Pharmacia Fine Chemicals, Inc., Piscataway, N.J.), and the standard curves relating elution quotient to the logarithm of molecular weight were interpolated to obtain the molecular weight values of the unknowns.

Immunological methods. Specific anti-exo- $\beta$-glucanase sera were prepared by immunizing rabbits against purified exo- $\beta$-glucanases, following an immunization schedule recommended in Methods in Immunology and Immunochemistry (27). The animals were handled in accordance with the recommendations of the National Institutes of Health (United States). Each of four female adult Dutch Belted rabbits received an intradermal injection of $0.6 \mathrm{ml}$ of enzyme solution mixed with Freund complete adjuvant (Difco Laboratories, Detroit, Mich.). Each emulsion contained ca. $0.5 \mathrm{mg}$ of enzyme protein. Two months after the initial immunization, intravenous boosters containing $0.2 \mathrm{mg}$ of purified enzyme protein in physiological saline were administered at 2 -week intervals until satisfactory serum titers were obtained. The rabbits were then starved overnight, and 20 to 40 $\mathrm{ml}$ of blood was drawn by venous puncture of the ear and collected in petrolatum-coated tubes. These were incubated at $37^{\circ} \mathrm{C}$ for $1 \mathrm{~h}$ to speed up coagulation and were then stored overnight in the cold to allow clot retraction. The plasma was decanted and subsequently treated as described in detail by Champion et al. (3). The immunological distances among the enzyme proteins were measured by the microcomplement fixation technique as described by these authors (3). Each set of complement fixation coordinates (log serum concentration; percent complement fixed at peak) that did not significantly deviate from linearity were individually used to calculate immunological distance values, which were then averaged for each pair of antigens compared. As a guide in evaluating the experimental accuracy of each average value, the product of the slope ratios (SR) and the standard deviations (SD) of the immunological distances was calculated, and it is reported for every test as SR $\times$ SD.

A large difference between the slopes of two complement fixation curves may be an indication that the proteins being compared differ from each other by features other than their amino acid sequences. In 
such cases, the validity of immunological distance as a measure of relatedness is uncertain. Since the SD, in this case, is mostly an expression of experimental variation, the product $S R \times S D$ is a better index for the reliability (when it has a low value) of each immunological distance measurement reflecting primary structure differences. Thus, immunological distances for which the SR $\times \mathrm{SD}$ values are in excess of about 30 should be considered with circumspection.

\section{RESULTS}

Molecular weights of yeast exo- $\beta$-glucanases. The strains of the species of Kluyveromyces studied are listed in Table 1, together with the molecular weights of their principal exo- $\beta$-glucanase components. Most of these enzymes have a molecular weight of approximately $40 \times 10^{3}$. Those of $K$. delphensis, $K$. vanudenii, and $K$. veronae, however, were significantly lower. The molecular weights of exo- $\beta$-glucanases of other ascomycetous yeasts ranged from $24 \times 10^{3}$ to $63 \times 10^{3}$ (Table 2). Surprisingly, these two extreme values were determined for two species of the same genus, Schizosaccharomyces.

A preliminary survey of basidiomycetous yeasts, including representatives of the genera Aessosporon, Filobasidium, Leucosporidium, Phaffia, and Rhodosporidium, was also made. All were characterized by levels of exo- $\beta$-glucan-

TABLE 1. Molecular weights of the exo- $\beta$ glucanases of the type strains of the species of Kluyveromyces and as determined by gel exclusion chromatography on Bio-Gel P-100 or P.150

\begin{tabular}{|c|c|c|c|}
\hline Species & $\begin{array}{c}\text { UCD- } \\
\text { FS\&T } \\
\text { strain no. }\end{array}$ & $\begin{array}{c}\mathrm{CBS}^{b} \\
\text { strain no. }\end{array}$ & $\begin{array}{c}\text { Mol wt } \\
\left(\times 10^{3}\right)\end{array}$ \\
\hline $\begin{array}{c}\text { Kluyveromyces aestu- } \\
\text { arii }\end{array}$ & $61-29$ & 4438 & 43 \\
\hline$K$. africanus . . . . & $57-16$ & 2517 & 42 \\
\hline K. bulgaricus & $71-13$ & 2762 & 41 \\
\hline K. cicerisporus & $71-14$ & 4857 & 41 \\
\hline K. delphensis. & $56-2$ & 2170 & 33 \\
\hline K. dobzhanskii . & $50-45$ & 2104 & 42 \\
\hline K. drosophilarum & $51-130$ & 2105 & 39 \\
\hline$K$. fragilis ....... & $71-58$ & 397 & 41 \\
\hline$K$. lactis & $71-59$ & 683 & 41 \\
\hline K. lodderi & $70-3$ & 2757 & 39 \\
\hline K. marxianus & $55-82$ & 712 & 41 \\
\hline$K$. phaffii .... & $70-5$ & 4417 & 42 \\
\hline$K$ phaseolosporus & $50-80$ & 2103 & 39 \\
\hline$K$. polysporus ..... & $57-17$ & 2163 & 43 \\
\hline$K$. vanudenii & $70-4$ & 4372 & 35 \\
\hline$K$. veronae .... & $55-41$ & 2803 & 33 \\
\hline K. wickerhamii & $54-210$ & 2745 & 41 \\
\hline K. wikenii ... & $71-15$ & 5671 & 42 \\
\hline
\end{tabular}

${ }^{a}$ University of California, Davis, Department of Food Science and Technology.

${ }^{b}$ Centraalbureau voor Schimmelcultures, Delft, The Netherlands. ase activity which were so low that molecular weight determinations were impractical. It was noted, however, that these yeasts usually produced exo- $\beta$-glucanases with higher molecular weights than those found in ascomycetous yeasts, i.e., higher than $50 \times 10^{3}$.

Immunological comparison of yeast exo$\beta$-glucanases. The reference strains were selected for their ability to produce sufficient amounts of exo- $\beta$-glucanase with adequate stability and for their postulated phylogenetic relationships as determined by other methods (8). The results shown in Tables 3 through 5 illustrate data obtained with reference strains of $K$. fragilis, $K$. phaseolosporus, and $K$. aestuarii, respectively. The sera against exo- $\beta$-glucanases from these three strains were highly specific, and all had high titers (i.e., 14,000, 9,000, and 17,000 , respectively). The data (Table 3 ) show that the exo- $\beta$-glucanases from the type strains of $K$. bulgaricus, $K$. cicerisporus, $K$. marxianus, and $K$. wikenii showed no significant differences from that of $K$. fragilis and (Table 4) that those from the type strains of $K$. delphensis, $K$. lactis, $K$. vanudenii, and $K$. drosophilarum were all, to some degree, quite similar to that of the type strain of $K$. phaseolosporus. The data in Table 5 show the absence of strong cross-reactivity between the exo- $\beta$-glucanase from $K$. aestuarii UCD-FS\&T $61-29$ and the other exo- $\beta$-glucanases tested.

Additional experiments were performed with the enzyme from Saccharomyces cerevisiae UCD-FS\&T 74-83 as a reference (Table 6). The exo- $\beta$-glucanase from this yeast proved to be a rather poor immunogen, for it produced antisera with titers lower than 1,000 ; this precluded its use in an extensive, in-depth survey. The exo$\beta$-glucanases from strains of Saccharomyces chevalieri, $S$. italicus, and $S$. uvarum were the only ones to react, each giving reactions of nearidentity with $S$. cerevisiae UCD-FS\&T 74-83.

\section{DISCUSSION}

Comparison of molecular weights of yeast exo- $\beta$-glucanases. Yeast exo- $\beta$-glucanases are somewhat diverse in properties such as their kinetics of hydrolysis (Table 7), but most of those surveyed are generally similar in their substrate specificities and their responses to $\mathrm{pH}$. They hydrolyze laminaran [a $\beta$ - $(1 \rightarrow 3)$-glucan] and pustulan [a $\beta-(1 \rightarrow 6)$-glucan] by the successive removal of glucose residues from the nonreducing end. In $K$. aestuarii, it was shown (M. A. Lachance, Ph.D. dissertation, University of California, Davis, 1977) that the hydrolysis product, D-glucose, retains the $\beta$ configuration, but whether other yeast glucanases cause an anomeric inversion is not known. Their action on 
TABLE 2. Molecular weights of exo- $\beta$-glucanases from species of various yeast genera and as determined by gel exclusion chromatography on Bio-Gel P-100 or P-150

\begin{tabular}{|c|c|c|c|}
\hline Species & UCD-FS\&T strain no. & CBS strain no. & $\begin{array}{c}\text { Mol wt } \\
\left(\times 10^{* 4}\right)\end{array}$ \\
\hline Debaryomyces cantarellii. & $60-25^{b}$ & 4349 & 43 \\
\hline D. hansenii . . . . . . . . . . . . . . . & $74-86^{b}$ & 767 & 38 \\
\hline 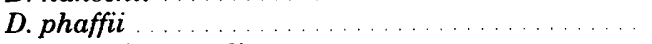 & $60-24^{b}$ & 4346 & 43 \\
\hline Dekkera intermedia ...... & $71-12$ & & 48 \\
\hline Hanseniaspora valbyensis & $68-23^{b}$ & 479 & 38 \\
\hline Hansenula anomala & C- $366^{b}$ & 5759 & 42 \\
\hline Lipomyces starkeyi . . . . . . . . . . . . . . & $55-103$ & & 40 \\
\hline Lodderomyces elongisporus . . . . . . . . . . . . & $68-17$ & 2605 & 33 \\
\hline Metschnikowia bicuspidata & $67-10^{b}$ & 5575 & 43 \\
\hline Nadsonia elongata ......... & $61-42^{b}$ & 2594 & 30 \\
\hline N. fulvescens . . . . . . . . & $61-44^{b}$ & 2996 & 32 \\
\hline Pichia membranaefaciens . . . . . . . . . . . . . & $57-22^{b}$ & 107 & 38 \\
\hline P. polymorpha ........... & $57-25^{b}$ & 186 & 40 \\
\hline \multicolumn{4}{|l|}{ Saccharomyces group I } \\
\hline S. cerevisiae & $74-83$ & & 51 \\
\hline$\ldots \ldots \ldots \ldots \ldots$ & $61-22^{b}$ & 400 & 53 \\
\hline$\ldots \ldots \ldots \ldots \ldots$ & C-105 & & 54 \\
\hline S. uvarum & $55-48^{b}$ & 395 & 55 \\
\hline \multicolumn{4}{|l|}{ Saccharomyces group II } \\
\hline S. bisporus ........... & $66-24^{b}$ & 702 & 59 \\
\hline S. rouxii ............. & $51-49$ & & 49 \\
\hline \multicolumn{4}{|l|}{ Saccharomyces group III } \\
\hline S. rosei .............. & $72-50^{b}$ & 817 & 41 \\
\hline S. saitoanus . . . . . . & $75-2^{b}$ & 705 & 38 \\
\hline Saccharomycodes ludwigii . . . . . . . . . . . . & $72-128$ & & 51 \\
\hline Schizosaccharomyces japonicus var. japonicus ... & $71-26^{b}$ & 354 & 28 \\
\hline S. japonicus var. versatilis $\ldots \ldots \ldots \ldots \ldots \ldots$ & $60-255$ & & 24 \\
\hline S. malidevorans . . . & $70-49^{b}$ & 5557 & 63 \\
\hline S. octosporus ..... & C-103 & & 57 \\
\hline S. pombe ............... & C-277 & & 38 \\
\hline Schwanniomyces alluvius & $54-83^{b}$ & 4516 & 37 \\
\hline S. castellii ................ & $53-3$ & 2863 & 36 \\
\hline S. occidentalis & $73-2^{b}$ & 1153 & 37 \\
\hline S. persoonii . . . . . . . . & $61-9^{b}$ & 2169 & 40 \\
\hline Trigonopsis variabilis . . . . . . . & C-179 & & 38 \\
\hline Wickerhamia fluorescens . . . . . . . . . . . . & $60-5^{b}$ & 4564 & 43 \\
\hline Wingea robertsii $\ldots \ldots \ldots \ldots \ldots \ldots$ & $60-22^{b}$ & 2934 & 54 \\
\hline
\end{tabular}

${ }^{a}$ See footnotes of Table 1 for explanations of abbreviations.

${ }^{b}$ Type strain.

the $\beta-(1 \rightarrow 3)$ linkage is generally more pronounced than on $\beta-(1 \rightarrow 6)$-linked glucans, but it is possible that the observed differences in velocity could be due to structural differences between laminaran and pustulan that are independent of their polymeric linkage. When the activation energies for these two substrates were calculated for the exo- $\beta$-glucanase from $K$. aestuarii (6), the two values were not far apart. However, the apparent specificity of that enzyme, as evaluated by comparing the $V_{\max } / K_{m}$ ratios obtained for laminaran and pustulan, is clearly in favor of the $\beta$ - $(1 \rightarrow 3)$-linked substrate. All yeast exo- $\beta$-glucanases that attack glucans from the nonreducing end also hydrolyze $p$-nitrophenyl- $\beta$-D-glucoside and a variety of other synthetic $\beta$-glucosides. The significance of these physical-chemical properties in relation to evolution of the enzyme is not clear, especially since their actual function in yeast morphogenesis is not known.

The interest of the results presented here lies essentially in their interpretation and their application to the knowledge of yeast phylogeny and to yeast taxonomy. The molecular weight distribution of exo- $\beta$-glucanases from ascomycetous yeasts is striking in its diversity (Table 2 ). However, it appears that yeasts which share certain basic characteristics have exo- $\beta$-glucanases that are not greatly different in size. For example, the strains of the species of Debaryomyces, Hansenula, Kluyveromyces, Pichia, 
INT. J. Syst. BaCteriol.

TABLE 3. Immunological comparison of exo- $\beta$-glucanases from the type strains of various species of yeasts, using Kluyveromyces fragilis UCD.FS\&T $71-58$ as the reference strain ${ }^{a}$

\begin{tabular}{|c|c|c|c|c|}
\hline Species & $\begin{array}{l}\text { UCD-FS\&T } \\
\text { strain no. }\end{array}$ & $N^{c}$ & $\begin{array}{c}\text { Immunological } \\
\text { distance }^{d}\end{array}$ & $\mathrm{SD} \times \mathrm{SR}^{\prime}$ \\
\hline Kluyveromyces wikenii & $71-15$ & 4 & -1 & 16 \\
\hline K. cicerisporus $\ldots \ldots \ldots \ldots \ldots \ldots \ldots$ & $71-14$ & 4 & -1 & 4 \\
\hline$\ldots \ldots \ldots \ldots \ldots \ldots$ & $71-13$ & 3 & 2 & 4 \\
\hline$\ldots \ldots \ldots \ldots \ldots \ldots$ & $55-82$ & 4 & 2 & 8 \\
\hline$\ldots \ldots \ldots \ldots$ & $61-29$ & 3 & 159 & 14 \\
\hline$\ldots \ldots \ldots \ldots \ldots$ & $57-17$ & 4 & 163 & 59 \\
\hline$K$ africanus $\ldots \ldots \ldots \ldots \ldots \ldots \ldots \ldots \ldots \ldots \ldots$ & $57-16$ & 4 & 168 & 38 \\
\hline$\ldots \ldots \ldots \ldots \ldots \ldots \ldots$ & $55-41$ & 2 & 186 & 54 \\
\hline K. vanudenii ......... & $70-4$ & 2 & 199 & 26 \\
\hline Debaryomyces phaffii ............... & $60-24$ & 2 & 202 & 333 \\
\hline Kluyveromyces lactis . . . . . . . . . . & $71-59$ & 4 & 213 & 72 \\
\hline$K$. delphensis $\ldots \ldots \ldots \ldots \ldots \ldots \ldots \ldots$ & $56-2$ & $\mathrm{NR}^{f}$ & & \\
\hline 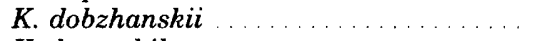 & $50-45$ & NR & & \\
\hline$K$. drosophilarum . . . . . . . . . . & $51-130$ & NR & & \\
\hline$\ldots \ldots \ldots \ldots \ldots$ & $70-3$ & NR & & \\
\hline 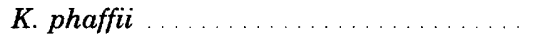 & $70-5$ & NR & & \\
\hline 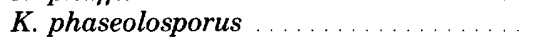 & $50-80$ & NR & & \\
\hline K. wickerhamii & $54-210$ & NR & & \\
\hline Dekkera intermedia .... & $71-12$ & NR & & \\
\hline Hansenula anomala $\ldots .$. & C-366 & NR & & \\
\hline Hanseniaspora valbyensis . . . . . . . . . & $68-23$ & NR & & \\
\hline Lodderomyces elongisporus . . . . . . . & $68-17$ & NR & & \\
\hline Metschnikowia bicuspidata . . . . . . . . & $67-10$ & NR & & \\
\hline Pichia membranaefaciens . . . . . . . . & $57-22$ & $N R$ & & \\
\hline Saccharomyces rosei ............... & $72-50$ & NR & & \\
\hline S. uvarum ............ & $55-48$ & NR & & \\
\hline Schwanniomyces castellii & $58-3$ & NR & & \\
\hline
\end{tabular}

" The homologous titration slope was 271.

${ }^{b}$ University of California, Davis, Department of Food Science and Technology.

${ }^{c} N$, Number of points used in calculating the immunological distance.

${ }^{d}$ Immunological distance $=100 \log$ immunological dissimilarity (cf. reference 3 ).

${ }^{e} \mathrm{SD} \times \mathrm{SR}$, Product of the standard deviation of immunological distances calculated from each pair of coordinates and the ratio of the slopes of each titration curve.

${ }^{f} \mathrm{NR}$ indicates either that no detectable complement fixation was observed or that excessive anti-complementarity was encountered.

TABLE 4. Immunological comparison of exo- $\beta$-glucanases from the type strains of various species of yeasts, using Kluyveromyces phaseolosporus UCD-FS\&T 50-80 as the reference strain ${ }^{a}$

\begin{tabular}{|c|c|c|c|c|}
\hline Species & $\begin{array}{c}\text { UCD-FS\&T } \\
\text { strain } \\
\text { no. } \\
\end{array}$ & $N$ & $\begin{array}{l}\text { Immunological } \\
\text { distance }\end{array}$ & $\mathrm{SD} \times \mathrm{SR}$ \\
\hline Kluyveromyces delphensis . . . . . . . . . & $56-2$ & 4 & 10 & 4 \\
\hline$K$. lactis $\ldots \ldots \ldots$ & $71-59$ & 3 & 15 & 2 \\
\hline K. vanudenii & $70-4$ & 3 & 20 & 1 \\
\hline K. drosophilarum & $51-130$ & 3 & 27 & 2 \\
\hline K. dobzhanskii & $50-45$ & 3 & 134 & 58 \\
\hline K. africanus & $57-16$ & 2 & 186 & 1 \\
\hline K. wickerhamii & $54-210$ & 4 & 206 & 41 \\
\hline$K$. aestuarii $\ldots \ldots$ & $61-29$ & 2 & 209 & 3 \\
\hline$\ldots \ldots \ldots \ldots \ldots \ldots \ldots$ & $71-58$ & NR & & \\
\hline K. lodderi . . . & $70-3$ & NR & & \\
\hline$K$. polysporus . . . . . . . & $57-17$ & NR & & \\
\hline Debaryomyces cantarellii & $60-25$ & NR & & \\
\hline Saccharomyces cerevisiae & $74-83$ & NR & & \\
\hline 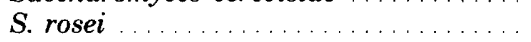 & $72-50$ & NR & & \\
\hline
\end{tabular}

${ }^{a}$ The homologous titration slope was 291. See footnotes $b$ through $f$ of Table 3 for explanations of abbreviations. 
TABLE 5. Immunological comparison of exo- $\beta$-glucanases from the type strains of various species of yeasts, using Kluyveromyces aestuarii UCD-FS\&T 61.29 as the reference strain ${ }^{a}$

\begin{tabular}{|c|c|c|c|c|}
\hline Species & $\begin{array}{c}\text { UCD-FS\&T } \\
\text { strain } \\
\text { no. }\end{array}$ & $N$ & $\begin{array}{l}\text { Immunological } \\
\text { distance }\end{array}$ & $\mathrm{SD} \times \mathrm{SR}$ \\
\hline Kluyveromyces drosophilarum . . . . . . . & $51-130$ & 3 & 161 & 2 \\
\hline$K$ fragilis $\ldots \ldots \ldots \ldots \ldots$ & $71-58$ & 3 & 162 & 1 \\
\hline K. wickerhamii & $54-210$ & 2 & 163 & 2 \\
\hline K. africanus . . & $57-16$ & 2 & 170 & 11 \\
\hline K. lactis . . . . . . & $71-59$ & 2 & 173 & 1 \\
\hline Dekkera intermedia & $71-12$ & NR & & \\
\hline Hansenula anomala $\ldots \ldots$ & C-366 & NR & & \\
\hline Lodderomyces elongisporus . . . . . . & $68-17$ & NR & & \\
\hline Pichia membranaefaciens . . . . . . . . . & $57-22$ & NR & & \\
\hline Saccharomyces rosei . . . . . . . . . . & $72-50$ & NR & & \\
\hline 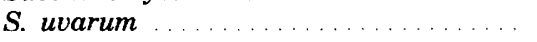 & $55-48$ & NR & & \\
\hline
\end{tabular}

" The homologous titration slope was 263. See footnotes $b$ through $f$ of Table 3 for explanations of abbreviations.

TABLE 6. Immunological comparison of exo-B-glucanases from various species of yeasts, using Saccharomyces cerevisiae UCD-FS\&T 74-83 as the reference strain ${ }^{a}$

\begin{tabular}{|c|c|c|c|c|}
\hline Species & $\begin{array}{c}\text { UCD-FS\&T } \\
\text { strain } \\
\text { no. }\end{array}$ & $N$ & $\begin{array}{l}\text { Immunological dis- } \\
\text { tance }\end{array}$ & $\mathrm{SD} \times \mathrm{SR}$ \\
\hline Saccharomyces italicus & C-105 & 3 & 5 & 8 \\
\hline S. uvarum ............ & $55-48$ & 4 & 11 & 7 \\
\hline S. chevalieri ..... & $61-22$ & 3 & 16 & 10 \\
\hline S. bisporus ... & $66-24$ & NR & & \\
\hline S. rosei ... & $72-50$ & NR & & \\
\hline S. rouxii . . . . . . . & $51-49$ & NR & & \\
\hline Debaryomyces cantarellii & $60-25$ & NR & & \\
\hline Kluyveromyces fragilis . . . . . . . . . & $71-58$ & NR & & \\
\hline Lodderomyces elongisporus . . . . . . . . & $68-17$ & NR & & \\
\hline
\end{tabular}

${ }^{a}$ The homologous titration slope was 245. See footnotes $b$ through $f$ of Table 3 for explanations of abbreviations.

TABLE 7. Comparison of some physical-chemical properties of various yeast exo- $\beta$-glucanases

\begin{tabular}{|c|c|c|c|c|c|c|c|c|c|}
\hline \multirow[b]{2}{*}{ Species $^{a}$} & \multicolumn{2}{|c|}{ Laminaran } & \multicolumn{2}{|c|}{ Pustulan } & \multicolumn{2}{|c|}{$\mathrm{pNPG}^{h}$} & \multicolumn{3}{|c|}{ pH activity } \\
\hline & $V_{\max }{ }^{c}$ & $\begin{array}{c}K_{m} \\
(\mathrm{mg} / \mathrm{ml})\end{array}$ & $V_{\max }$ & $\begin{array}{c}K_{m} \\
(\mathrm{mg} / \mathrm{ml})\end{array}$ & $V_{\max }$ & $\underset{(\mathrm{mM})}{K_{m}}$ & $\mathrm{pK}_{1}$ & $\mathrm{pH}_{\text {opl }}$ & $\mathbf{p K}_{2}$ \\
\hline $\begin{array}{l}\text { Candida utilis (12) } \\
\text { Cryptococcus albidus var. aerius }\end{array}$ & & 1.2 & & 0.7 & & 3.1 & & 5.5 & $\cdot$ \\
\hline (11) $\ldots \ldots \ldots \ldots \ldots$ & & 0.1 & & 0.3 & & 0.007 & 3.5 & 5.5 & 7.0 \\
\hline Hansenula anomala (1) . . . . . & 54 & 5 & 7.2 & 5.9 & 1.8 & 5.4 & & 5.5 & \\
\hline Kluyveromyces aestuarii (6) . . & 260 & 1.7 & 3.9 & 4.5 & 24 & 5.0 & 3.2 & 5.2 & 6.0 \\
\hline K. fragilis (1) . . . . . . . & 83 & 1.2 & 7.4 & 1.8 & 2.2 & 0.6 & 4.2 & 5.5 & 7.0 \\
\hline K. phaseolosporus (16) $\ldots \ldots$ & & 2 & & 35.7 & & 6 & 5.2 & 6.0 & 7.1 \\
\hline Saccharomyces cerevisiae (1) . & 9.5 & 14 & 3.8 & 3.6 & 0.7 & 215 & & 5.5 & \\
\hline var. versatilis (4) & 350 & 6.2 & 52 & 166 & & & 3.6 & 5.2 & 6.8 \\
\hline
\end{tabular}

a The numbers after the species name are literature citations.

${ }^{b}$ pNPG, $p$-Nitrophenyl- $\beta$-D-glucoside.

c $V_{\text {max }}$, Micromoles of glucose released per minute at $30^{\circ} \mathrm{C}$ and $\mathrm{pH} 5.5$.

Saccharomyces group III, and Schwanniomyces included in this survey all gave values clustering around $40 \times 10^{3}$. Species of these genera not only share certain properties, particularly in their sexual life cycles, but also exhibit important differences; this has resulted in the present state of confusion regarding their classification $(7,15,20,22)$. In contrast, the species of Schizosaccharomyces appeared highly diverse with respect to the size of their exo- $\beta$-glucanases. This possibly indicates that this genus is either polyphyletic or very ancient: 
A few discrepancies were noted between molecular weights reported here and those previously reported in the literature. For example, Abd-E1-Al and Phaff (1) calculated values of 22 $\times 10^{3}, 30 \times 10^{3}$, and $40 \times 10^{3}$ for the exo- $\beta$ glucanases from strains of $K$. fragilis, $H$. anom$a l a$, and $S$. cerevisiae, respectively. These authors used column chromatography, as we did, but their columns were packed with cross-linked dextran (Sephadex) gels (for which these enzymes show significant affinity) eluted with buffers of lower ionic strength $(0.2 \mathrm{M})$. This results in lower apparent molecular weights. We obtained values of $41 \times 10^{3}, 42 \times 10^{3}$, and $51 \times$ $10^{3}$, respectively, for the same yeast strains. During the purification of exo- $\beta$-glucanases from strains of $K$. aestuarii and $K$. phaseolosporus, it was observed (Lachance, Ph.D. dissertation) that, when these enzymes were chromatographed on different grades of Sephadex, their elution volumes indicated apparent molecular weights of approximately $22 \times 10^{3}$. The enzyme from a strain of $K$. phaseolosporus similarly eluted from Sephacryl S-200 with an apparent molecular weight of $19 \times 10^{3}(21)$. The molecular weights reported here and determined on polyacrylamide columns are thus of a relative, although more realistic, nature. The influence of carbohydrate content of the different exo- $\beta$-glucanases on their chromatographic behavior is not known.

The standard deviation of molecular weights of exo- $\beta$-glucanases shown to be very similar by microcomplement fixation, or those from yeasts with high degrees of DNA complementarity, was $1.7 \times 10^{3}$.

Immunological comparisons of exo- $\beta$ glucanases. Even though exo- $\beta$-glucanases in the genus Kluyveromyces appeared rather homogeneous with respect to their molecular weights, an appreciable degree of diversity was detected by the microcomplement fixation technique. A range of immunological distances from 0 to 27 was found for eight of our comparisons, but all other values were 130 or higher, indicating that the primary structure of exo- $\beta$-glucanase is not highly conserved in evolutionary time. If the relationship of four units of immunological distance for every $1 \%$ amino acid replacement, as found for bird lysozyme (3), holds equally for yeast exo- $\beta$-glucanases, many of these enzymes in Kluyveromyces differ from each other by at least $40 \%$ of their sequences. It follows that exo$\beta$-glucanases may not be proteins of choice for deriving general yeast phylogenies.

The accuracy of high immunological distance values (i.e., $>130$ ) can be questioned, but the one reciprocal test ( $K$. fragilis $\times K$. aestuarii) to result from this study gave concordant values of
$159(\mathrm{SR} \times \mathrm{SD}=14$; Table 3$)$ and $162(\mathrm{SR} \times \mathrm{SD}$ $=1$; Table 5). Higher values should nevertheless be considered with caution (V. M. Sarich, personal communication).

Various degrees of immunological similarity between exo- $\beta$-glucanases from different yeasts may take on different significances, depending on whether or not gene exchange is possible among the species compared. Our survey provided no clue as to the importance of intraspecific gene polymorphism in yeast, since it is not known whether or not in nature the "species" compared are capable of effective genetic recombination among each other. Wickerham and Burton $(25,26)$ induced, under laboratory conditions, exchange of genetic material, even in species that have low degrees of DNA complementarity (8). However, they gave no evidence on fertility or segregational patterns of the $F_{1}$ generation of these crosses.

Conversely, natural genetic exchange between "species" of Kluyveromyces may be a minor factor, so that, in practice, the divergence observed between the informational macromolecules (DNA, ribonucleic acid, and proteins) of these yeasts is almost exclusively the result of accumulated mutations through evolutionary time.

When the results of our immunological survey were compared with the relationships proposed by van der Walt (19) and by Poncet (14), an appreciable degree of agreement was apparent, but major discrepancies were also noted. For example, high degrees of immunological similarity were found between exo- $\beta$-glucanases from species with different spore shapes or from species which showed relatively little similarity by factor analysis of their expressed phenotypes. In other cases, species deemed identical by factor analysis showed low degrees of immunological cross-reactivity. There was, however, (with one exception [see below]) an excellent correlation between DNA/DNA complementarity data (2, $8,9)$ and the immunological comparison. This is in support of treating the species of Kluyveromyces as distinct genetic lineages rather than of considering their structurally different glucanases as alleles of the same polymorphic gene.

The few comparisons performed with Saccharomyces strains with reference to Saccharomyces cerevisiae (Table 6) were also in agreement with the DNA reassociation patterns obtained with these strains (2).

Assuming that all presently defined "species" of Kluyveromyces are derived from a common ancestor and have not undergone reticulate evolution, the immunological distances found between the exo- $\beta$-glucanases of each of these species can be taken as an index of their time of 
divergence. From this, the following conclusions can be drawn.

(i) The choice of ascospore shape as a basis for establishing two lines of development in the genus Kluyveromyces appears unjustified, because in two instances, "species" with reniform spores were shown to be immunologically closely related to "species" producing spherical ascospores (i.e., $K$. fragilis and $K$. marxianus, with $K$. bulgaricus, $K$. cicerisporus, and $K$. wilkenii, respectively; $K$. delphensis, $K$. drosophilarum, and $K$. phaseolosporus, with $K$. lactis and $K$. vanudenii, respectively); conversely, many "species" with similar spore morphologies showed little resemblance in their exo- $\beta$-glucanases.

(ii) Combining our results with those obtained by DNA/DNA base sequence comparisons $(2,8$, 9), the following should be retained as separate species: $K$. aestuarii, $K$. africanus, $K$. dobzhanskii, $K$. lodderi, $K$. phaffii, $K$. polysporus, $K$. veronae, and $K$. wickerhamii.

(iii) The close phenotypic similarities $(14,19)$ observed between (a) $K$. aestuarii and $K$. lactis, (b) $K$. delphensis and $K$. phaffii or $K$. africanus, (c) $K$. lodderi and $K$. polysporus, and (d) $K$. phaseolosporus and $K$. wickerhamii are not supported by the immunological data or by DNA/DNA reassociation experiments (7); they appear to be the results of either evolutionary parallelism or, more likely, convergence.

(iv) The intermediate immunological distances found between the exo- $\beta$-glucanases from $K$. phaseolosporus, on the one hand, and those from $K$. delphensis, $K$. lactis, $K$. vanudenii, and $K$. drosophilarum, on the other hand, are indications that these yeasts share a relatively recent common ancestry.

$K$. lactis and $K$. vanudenii, which were shown to share $97 \%$ (relative values) of their DNA base sequences (8), do not significantly differ in their respective immunological distances from $K$. phaseolosporus (Table 4). These two organisms could therefore be considered as representatives of the same species. $K$. drosophilarum, the most distant from $K$. phaseolosporus among the strains of intermediate status (Table 4), showed $70 \%$ relative DNA reassociation with the latter (8).

The relatedness determined between $K$. delphensis and $K$. phaseolosporus was unexpected, in view of their relatively low degree of phenotypic similarity $(14,19)$ and low inferred DNA complementarity (H. Presley and H. J. Phaff, unpublished data).

(v) Four nomenspecies (K. bulgaricus, $K$. cicerisporus, $K$. wikenii, and $K$. marxianus) were found to have exo- $\beta$-glucanases identical in primary structure to that of $K$. fragilis. Martini (8) demonstrated a very high degree of DNA com- plementarity among the first three species, and Bicknell and Douglas (2) demonstrated the same between $K$. fragilis and $K$. marxianus. This suggests that these five yeasts are representatives of the same species.

A biological definition of yeast species will be possible in the future, when enough knowledge is acquired about genetic recombination among natural yeast populations. This will necessitate a thorough study of gene distribution for naturally occurring genetic polymorphisms over geographic gradients. Some progress in this area of research has been made for natural populations of Pichia heedii (13) and P. amethionina (16). In each of these yeasts genetic polymorphism was demonstrated over geographic gradients, and the physiological strains were capable of interbreeding.

Awaiting further knowledge, yeast taxonomists are still faced with the necessity of defining groups of yeast strains as "species," biological or not. Macromolecular comparisons provide taxonomists with an excellent tool for temporarily accomplishing this task. The classification of yeasts that have highly similar macromolecular sequences and that have undergone rapid divergence in some phenotypic properties (allowing occupation of new niches) remains a difficult problem, to be solved only by the judicious application of subjective judgments by experienced taxonomists.

\section{ACKNOWLEDGMENTS}

We are greatly indebted to Tomàs G. Villa for his kind cooperation, particularly in the purification of enzymes used in this work. Thanks are extended to Mary G. Miranda for her skillful assistance. We are grateful to Vincent $M$. Sarich, William T. Starmer, and John R. Whitaker for their helpful suggestions and comments.

This work has been made possible by fellowships awarded to M. A. Lachance by the National Research Council of Canada and by the Direction générale de l'Enseignement supèrieur, Ministère de l'Ėducation, Québec, Canada. Partial financial support of the project from the Chancellor's Patent Fund, University of California, Davis, and the donation of some rabbits by Paul E. Conley, Elk Grove, Calif., are gratefully acknowledged.

\section{REPRINT REQUESTS}

Address reprint requests to: H. J. Phaff, Department of Food Science and Technology, University of California, Davis, CA 95616.

\section{LITERATURE CITED}

1. Abd-El-Al, A. T. H., and H. J. Phaff. 1968. Exo- $\beta$ glucanases in yeast. Biochem. J. 109:347-360.

2. Bicknell, J. N., and H. C. Douglas. 1970. Nucleic acid homologies among species of Saccharomyces. J. Bacteriol. 101:505-512.

3. Champion, A. B., E. M. Prager, D. Watcher, and A. C. Wilson. 1974. Microcomplement fixation, p. 397-416. In C. A. Wright (ed.), Biochemical and immunological taxonomy of animals. Academic Press, Inc., London.

4. Fleet, G. H., and H. J. Phaff. 1975. Glucanases in Schiz- 
osaccharomyces. Isolation and properties of an exo- $\beta$ glucanase from the cell extracts and culture fluid of Schizosaccharomyces japonicus var. versatilis. Biochim. Biophys. Acta 401:318-332.

5. Lachance, M. A., and H. J. Phaff. 1975. A rapid method for monitoring the activity of certain carbohydrases. Anal. Biochem. 67:661-663.

6. Lachance M. A., T. G. Villa, and H. J. Phaff. 1977. Purification and partial characterization of an exo- $\beta$ glucanase from the yeast Kluyveromyces aestuarii. Can. J. Biochem. 55:1001-1006.

7. Lodder, J. (ed.). 1970. The yeasts-a taxonomic study. North Holland Publishing Co., Amsterdam.

8. Martini, A. 1973. Ibridazioni DNA/DNA tra species di lieviti del genere Kluyveromyces. Annal. Fac. Agrar. Univ. Studi Perugia 28:3-15.

9. Martini, A., and H. J. Phaff. 1973. The optical determination of DNA-DNA homologies in yeasts. Ann. Microbiol. 23:59-68.

10. Martini, A., H. J. Phaff, and S. A. Douglass. 1972 Deoxyribonucleic acid base composition of species in the yeast genus Kluyveromyces van der Walt emend. van der Walt. J. Bacteriol. 111:481-487.

11. Notario, V., T. G. Villa, T. Benitez, and J. R. Villanueva. 1976. $\beta$-Glucanases in the yeast Cryptococcus albidus var. aerius. Purification and separation of $\beta$ glucanases in asynchronous cultures. Can. J. Microbiol. 22:261-268.

12. Notario, V., T. G. Villa, and J. R. Villanueva. 1976 Purification of an exo- $\beta$-glucanase from cell-free extracts of Candida utilis. Biochem. J. 159:555-562.

13. Phaff, H. J., W. T. Starmer, Mary Miranda, and M. W. Miller, 1978. Pichia heedii, a new species of yeast indigenous to necrotic cacti in the North American Sonoran desert. Int. J. Syst. Bacteriol. 28:326-331.

14. Poncet, S. 1973. Taxonomie numérique du genre Kluy. veromyces. Mycopathol. Mycol. Appl. 51:267-281.

15. Price, C. W., G. B. Fuson, and H. J. Phaff. 1978. Genome comparison in yeast systematics: delimitation of species within the genera Schwanniomyces, Saccharomyces, Debaryomyces, and Pichia. Microbiol. Rev. 42:161-193.

16. Starmer, W. T., H. J. Phaff, M. Miranda, and M. W.
Miller. 1978. Pichia amethionina, a new heterothallic yeast associated with the decaying stems of cereoid cacti. Int. J. Syst. Bacteriol. 28:433-441.

17. van der Walt, J. P. 1956. Kluyveromyces-a new yeast genus of the Endomycetales. Antonie van Leeuwenhoek J. Microbiol. Serol. 22:265-272.

18. van der Walt, J. P. 1965. The emendation of the genus Kluyveromyces v. d. Walt. Antonie van Leeuwenhoek J. Microbiol. Serol. 31:341-348.

19. van der Walt, J. P. 1970. Kluyveromyces van der Walt emend. van der Walt, p. 316-378. In J. Lodder (ed.), The yeasts-a taxonomic study. North Holland Publishing Co., Amsterdam.

20. van der Walt, J. P., and E. Johannsen. 1975. The genus Torulaspora Lindner, p. 1-23. In CSIR research report no. 325. Council of Scientific Industrial Research, Pretoria, S. Africa.

21. Villa, T. G., M. A. Lachance, and H. J. Phaff. 1978. $\beta$-Glucanases of the yeast Kluyveromyces phaseolosporus: partial purification and characterization. Exp. Mycol. 2:12-25.

22. von Arx, J. A., L. Rodrigues de Miranda, M. Th. Smith, and D. Yarrow. 1977. The genera of yeasts and the yeast-like fungi, p. 1-42. In Studies in mycology, vol. 14. Centraalbureau voor Schimmelcultures, Baarn The Netherlands.

23. Whitaker, J. R. 1963. Determination of molecular weights of proteins by gel filtration on Sephadex. Anal. Chem. 35: 1950-1953.

24. Wickerham, L. J. 1951. Taxonomy of yeasts. USDA technical bulletin no. 1029. U.S. Department of Agriculture, Washington, D.C.

25. Wickerham, L. J., and K. A. Burton. 1956. Hybridization studies involving Saccharomyces lactis and Zygo saccharomyces ashbyi. J. Bacteriol. 71:290-295.

26. Wickerham, L. J., and K. A. Burton. 1956. Hybridization studies involving Saccharomyces fragilis and Zygosaccharomyces dobzhanskii. J. Bacteriol. 71:296302.

27. Williams, C. A., and M. W. Chase (ed.). 1967. Methods in immunology and immunochemistry, vol. 1. Preparation of antigens and antibodies. Academic Press Inc. New York. 